\title{
Lithogenic and biogenic particle fluxes on the Lomonosov Ridge (central Arctic Ocean) and their relevance for sediment accumulation: Vertical vs. lateral transport
}

\author{
Kirsten Fahl ${ }^{\mathrm{a}, *}$, Eva-Maria Nöthig ${ }^{\mathrm{b}}$ \\ ${ }^{a}$ Alfred Wegener Institute for Polar and Marine Research, Am Alten Hafen 26, 27568 Bremerhaven, Germany \\ ${ }^{\mathrm{b}}$ Alfred Wegener Institute for Polar and Marine Research, Am Handelshafen 12, 27570 Bremerhaven, Germany
}

Received 14 November 2006; received in revised form 19 April 2007; accepted 22 April 2007

Available online 3 May 2007

\begin{abstract}
Investigations of lithogenic and biogenic particle fluxes using long-term sediment traps are still very rare in the northern high latitudes and are restricted to the arctic marginal seas and sub-arctic regions. Here data on the variability of fluxes of lithogenic matter, $\mathrm{CaCO}_{3}$, opal, and organic carbon and biomarker composition from the central Arctic Ocean are presented for a 1-year period. The study was carried out on material obtained from a long-term mooring system equipped with two multi-sampling traps, at 150 and $1550 \mathrm{~m}$ depth, and deployed on the southern Lomonosov Ridge close to the Laptev Sea continental margin from September 1995 to August 1996. In addition, data from surface sediments were included in the study. Annual fluxes of lithogenic matter, $\mathrm{CaCO}_{3}$, opal, and particulate organic carbon were 3.9, 0.8, 2.6, and $1.5 \mathrm{~g} \mathrm{~m}^{-2} \mathrm{y}^{-1}$, respectively, in the shallow trap and $11.3,0.5,2.9$, and $1.05 \mathrm{~g} \mathrm{~m}^{-2} \mathrm{y}^{-1}$, respectively, in the deep trap.

Both the shallow and the deep trap showed significant variations in vertical flux over the year. Higher values were found from mid-July to the end of October (total mass flux of $75-130 \mathrm{mg} \mathrm{m}^{-2} \mathrm{~d}^{-1}$ in the shallow trap and $40-225 \mathrm{mg} \mathrm{m}^{-2} \mathrm{~d}^{-1}$ in the deep trap). During all other months, fluxes were fairly low in both traps (most total mass flux values $<10 \mathrm{mg} \mathrm{m}^{-2} \mathrm{~d}^{-1}$ ). The interval of increased fluxes can be separated into (1) a mid-July/August maximum caused by increased primary production as documented in high abundances of marine biomarkers and diatoms and (2) a September/October maximum caused by increased influence of Lena River discharge indicated by maximum lithogenic flux and large amounts of terrigenous/fluvial biomarkers in both traps. During September/October, total mass fluxes in the deep trap were significantly higher than in the shallow trap, suggesting a lateral sediment flux at greater depth. The lithogenic flux data also support the importance of sediment input from the Laptev Sea for the sediment accumulation on the Lomonosov Ridge on geological time scales, as indicated in sedimentary records from this region.
\end{abstract}

(C) 2007 Elsevier Ltd. All rights reserved.

Keywords: Central Arctic Ocean; Organic carbon flux; Biomarker; Sea ice; River discharge; Lateral transport

\footnotetext{
*Corresponding author. Tel.: + 4947148311578 ; fax: +4947148311923 .

E-mail addresses: Kirsten.Fahl@awi.de (K. Fahl), Eva-Maria.Noethig@awi.de (E.-M. Nöthig).
}

\section{Introduction}

The composition and quantity of lithogenic and biogenic matter and its vertical and lateral fluxes are poorly known in the Arctic Ocean. Data on total 
mass, lithogenic matter, carbonate $\left(\mathrm{CaCO}_{3}\right)$, opal, and particulate organic carbon (POC) fluxes can be obtained by means of sediment trap deployments. In the Arctic Ocean proper, however, sediment-trap data have not been available until now but have been restricted to marginal seas and subarctic areas (Hebbeln and Wefer, 1991; Hebbeln, 2000; Wassmann et al., 2004). In this context, the open Arctic Ocean area close to the Laptev Sea is especially important for Arctic oceanography.

The Laptev Sea (Fig. 1) is characterized by high export rates of sea ice and high input of suspended and dissolved material by Siberian rivers, both having a great influence on the sedimentary and chemical budgets of the entire Arctic Ocean (Eicken et al., 1997, 2000; Holmes et al., 2002; Stein and Fahl, 2004). A major contributor is the Lena River (discharge $=523 \mathrm{~km}^{3} / \mathrm{yr}$ ), transporting large amounts of dissolved and particulate material, i.e., chemical elements, lithogenic and terrestrial/fluvial organic matter, and nutrients. The annual discharge of total suspended sediments by the Lena River is $20.7 \times 10^{6}$ tons (Holmes et al., 2002; Rachold et al., 2004); particulate organic carbon supply is estimated to reach about $1.2 \times 10^{6}$ tons per year. The Lena River is an important freshwater source characterized by a seasonally pulsed inflow in June/July and moderate inflow during May and August/September (Fig. 1). During this short season of strong freshwater discharge, water masses on the Laptev Sea shelf are characterized by low salinities of 4-28 (Dmitrenko et al., 1999), which can be encountered far off the shelf, causing stratification of the surface waters.

Here, we present the first record of the annual variability and composition of particle fluxes in the Lomonosov Ridge area close to the Laptev Sea continental margin. The characterization of

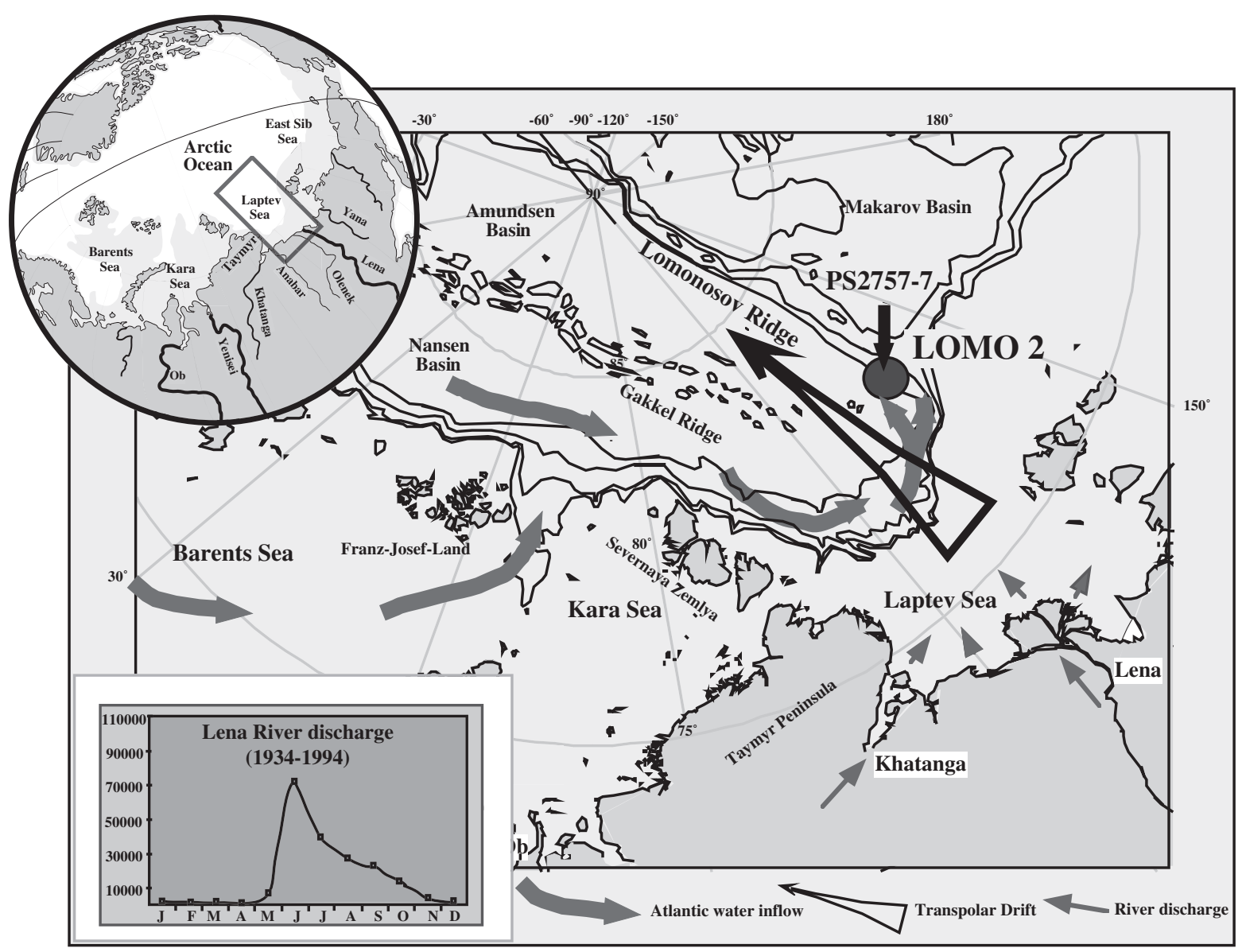

Fig. 1. Geographic map of the Eurasian part of the Arctic Ocean with the location of the moored sediment trap Lomo2. In the lower left corner, the annual variability of Lena river discharge is shown (http://www.R-ArcticNET.sr.unh.edu). 
the organic matter (here by biogeochemical bulk parameters and biomarkers) will give information about processes controlling export, degradation, and accumulation of the organic substances.

\section{Material and methods}

During the "Polarstern" Expedition ARK-XI/1 in 1995 (Rachor, 1997) a long-term mooring system with two cone-shaped multi-sampling traps (SMT 230 K.U.M.; sampling area $0.5 \mathrm{~m}^{2}$ ) was deployed at the almost permanently ice-covered western slope of the Lomonosov Ridge (Fig. 1, Table 1, Lomo2; $81^{\circ} 04.5^{\prime} \mathrm{N}, 138^{\circ} 54.0^{\prime} \mathrm{E}, 1712 \mathrm{~m}$ water depth; Daranall and Rudels, 1997). One trap was installed at $150 \mathrm{~m}$ below the sea surface and the other at $150 \mathrm{~m}$ above bottom at $1550 \mathrm{~m}$ depth. The total mass, POC, opal, and $\mathrm{CaCO}_{3}$ fluxes (Figs. 2a-d and Table 3) and sterol and fatty acid fluxes (Fig. 3 and Table 4) were measured for the period from September 1995 to August 1996.

The 20 collecting cups were filled with sterile filtered North Sea water made up to a salinity of 40 with $\mathrm{NaCl}$ and poisoned with $\mathrm{HgCl}_{2}$. After recovery the samples were stored at temperatures below $10^{\circ} \mathrm{C}$ before analysis (ca. 4 months). Samples were split wet into aliquots after Fischer and Wefer (1991).

Table 1

Sampling interval of the sediment trap Lomo2 $\left(81^{\circ} 04.5^{\prime} \mathrm{N}\right.$, $\left.138^{\circ} 54.0^{\prime} \mathrm{E}\right)$

\begin{tabular}{llll}
\hline 150-1550 m & Start & End & Duration (days) \\
\hline Sept. 95/2 & 15.09 .1995 & 30.09 .1995 & 15 \\
Oct. 95/1 & 30.09 .1995 & 15.10 .1995 & 15 \\
Oct. 95/2 & 15.10 .1995 & 30.10 .1995 & 15 \\
Nov. 95/1 & 30.10 .1995 & 14.11 .1995 & 15 \\
Nov. 95/2 & 14.11 .1995 & 29.11 .1995 & 15 \\
Dec. 95/1 & 29.11 .1995 & 14.12 .1995 & 15 \\
Dec. 95/2 & 14.12 .1996 & 01.01 .1996 & 18 \\
Jan. 96 & 01.01 .1996 & 01.02 .1996 & 31 \\
Feb. 96 & 01.02 .1996 & 01.03 .1996 & 29 \\
March 96/1 & 01.03 .1996 & 16.03 .1996 & 15 \\
March 96/2 & 16.03 .1996 & 01.04 .1996 & 16 \\
April 96/1 & 01.04 .1996 & 16.04 .1996 & 15 \\
April 96/2 & 16.04 .1996 & 01.05 .1996 & 15 \\
May 96/1 & 01.05 .1996 & 15.05 .1996 & 14 \\
May 96/2 & 15.05 .1996 & 01.06 .1996 & 17 \\
June 96/1 & 01.06 .1996 & 16.06 .1996 & 15 \\
June 96/2 & 16.06 .1996 & 01.07 .1996 & 15 \\
July 96/1 & 01.07 .1996 & 16.07 .1996 & 15 \\
July 96/2 & 16.07 .1996 & 01.08 .1996 & 16 \\
Aug. 96/1 & 01.08 .1996 & 16.08 .1996 & 15 \\
\hline
\end{tabular}

Subsamples for total dry weight (DW), POC, $\mathrm{CaCO}_{3}$, opal, and biomarker (lipid) analyses were taken from each cup and analyzed according to the methods listed in Table 2. We did not correct the fluxes for dissolution in the sampling cups after particle collection (Bauerfeind, 2004). Thus, these fluxes shown here are minimum values.

In order to get information on the proportion of marine organic carbon we use the diatom-specific fatty acids cis-9-hexadecenoic acid $\left(\mathrm{C}_{16: 1(n-7)}\right)$, cis-11hexadecenoic acid $\left(\mathrm{C}_{16: 1(n-5)}\right)$, and all-cis-5,8,11,14,17eicosapentaenoic acid $\left(\mathrm{C}_{20: 5(n-3)}\right)$ for interpretation (Kates and Volcani, 1966; Ackman et al., 1968; Kattner et al., 1983; Fahl and Kattner, 1993; Graeve et al., 1994). All fatty acid components up to carbon chain length of 22 were determined in this study, however, and the data are available on doi:10.1594/PANGAEA.602289. The short-chain $n$-alkanes, which are also stated to be of marine origin (Blumer et al., 1971; Prahl and Muehlhausen 1989), and the corresponding long-chain components, indicating a terrigenous organic carbon source $(\mathrm{Ni}-$ chols et al. 1984; Prahl and Muehlhausen 1989; Yunker et al. 1995), occur only in trace amounts in the samples. In order to estimate the relevance of "terrestrial input" campesterol (24-methylcholest-5en- $\beta$-ol) and $\beta$-sitosterol (24-ethylcholest-5-en-3 $\beta$-ol), synthesized by higher plants (e.g. Huang and Meinschein 1976; Volkman 1986), were used.

All data are available in the data bank PANGAEA (doi:10.1594/PANGAEA.602289).

\section{Results and discussion}

The Lomonosov Ridge, crossing the Arctic Ocean from Greenland to the New Siberian Islands and separating the Eurasian and Amerasian basins, underlies an area with nearly permanent ice cover. Satellite passive microwave ice concentration data show that the southern Lomonosov Ridge, close to the Eurasian continental margin, is generally covered by more than $95 \%$ ice during most of the season, and even during summer ice concentration remains above 90\% (Haas and Eicken, 2001). Sea-ice cover in the study area, however, shows a distinct interannual variability, and sometimes ice-free areas occur (Comiso, 2002; Comiso and Parkinson, 2004; Bareiss and Görgen, 2005). Because of the extensive sea-ice cover and light limitation, primary production is restricted to a period of about 3 months during summer (Sakshaug, 2004). 


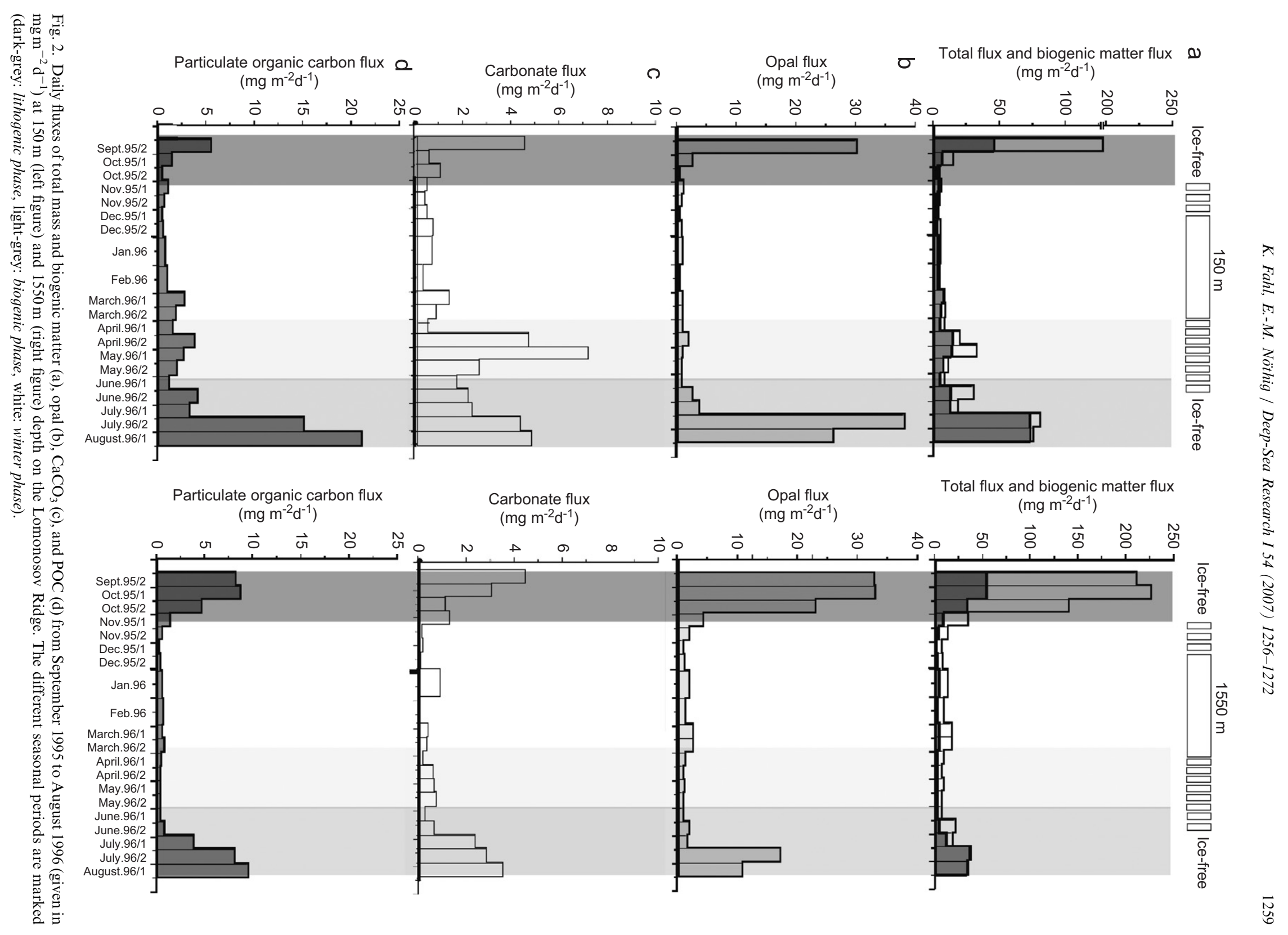



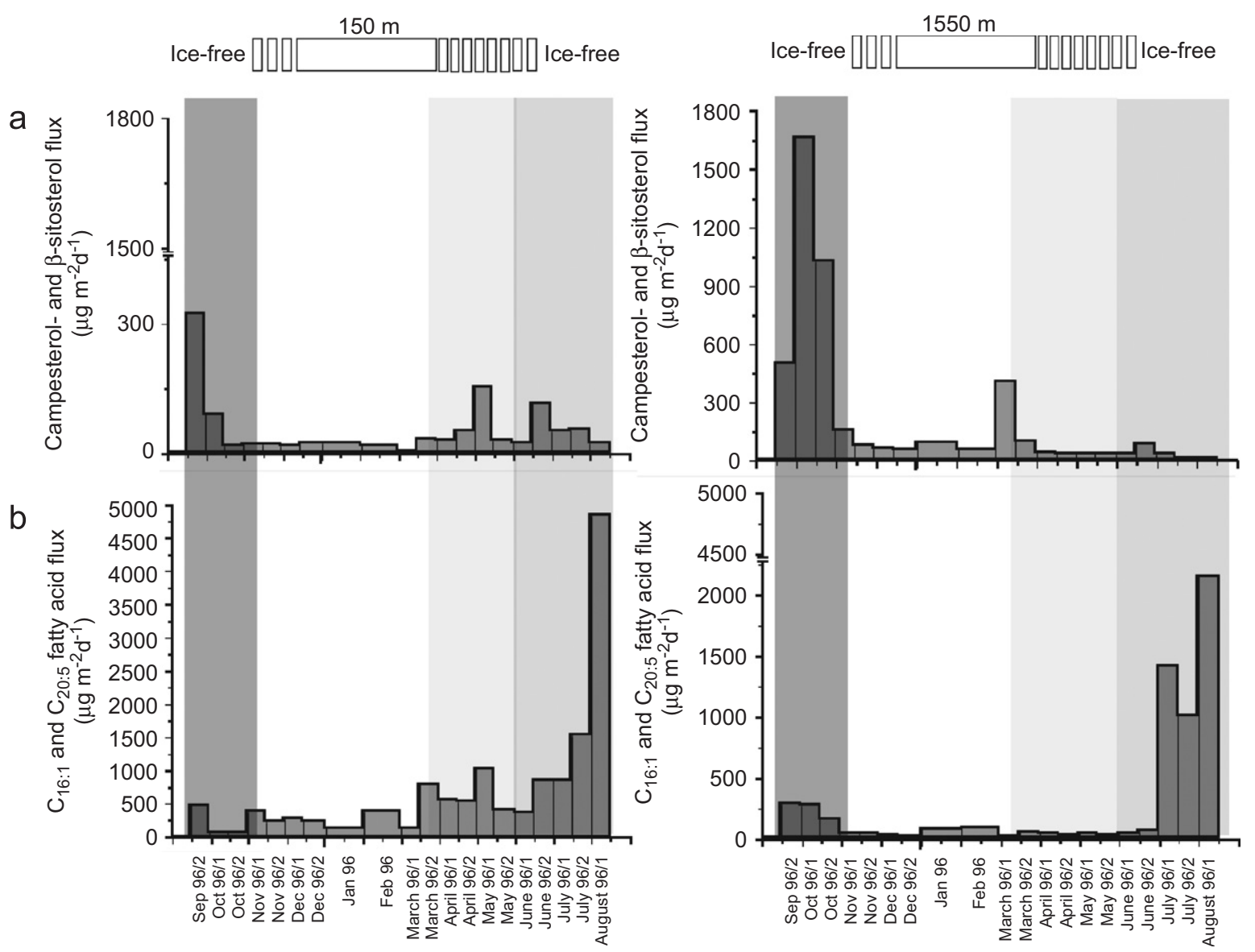

Fig. 3. Daily fluxes of the sum of campesterol and $\beta$-sitosterol (a) and the sum of $\mathrm{C}_{16: 1(n-7)}, \mathrm{C}_{16: 1(n-5)}$, and $\mathrm{C}_{20: 5(n-3)}$ (b) from September 1995 to August 1996 (given in $\mu \mathrm{g} \mathrm{m}^{-2} \mathrm{~d}^{-1}$ ) at $150 \mathrm{~m}$ (left figure) and $1550 \mathrm{~m}$ (right figure) depth on the Lomonosov Ridge. The different seasonal periods are marked (dark-grey: lithogenic phase, light-grey: biogenic phase, white: winter phase).

Table 2

Material and methods used to obtain the data (including references containing descriptions of the methods applied)

\begin{tabular}{|c|c|c|c|}
\hline & Parameter & Technique & Reference \\
\hline \multirow[t]{6}{*}{$\begin{array}{l}\text { Biogeochemical bulk } \\
\text { parameter }\end{array}$} & $\begin{array}{l}\text { Total mass (total dry } \\
\text { weight) }\end{array}$ & Weighing & $\begin{array}{l}\text { von Bodungen et al. } \\
\text { (1991) }\end{array}$ \\
\hline & Biogenic matter & $\begin{array}{l}\text { Calculation } \\
\text { Biogenic matter }=2 \times \mathrm{POC}+\mathrm{CaCO}_{3}+\mathrm{Opal} \\
(\mathrm{Opal}=2.1 \times \mathrm{bPSi})\end{array}$ & $\begin{array}{l}\text { von Bodungen et al. } \\
\text { (1991) }\end{array}$ \\
\hline & Lithogenic matter & Calculation (total matter-biogenic matter) & Modified after \\
\hline & Opal & Wet-alkaline digestion & $\begin{array}{l}\text { von Bodungen et al. } \\
\text { (1991) }\end{array}$ \\
\hline & $\mathrm{CaCO}_{3}$ & Mass loss by acidification and weighing & $\begin{array}{l}\text { von Bodungen et al. } \\
\text { (1991) }\end{array}$ \\
\hline & POC & Heraeus CHN-analyzer & $\begin{array}{l}\text { von Bodungen et al. } \\
\text { (1991) }\end{array}$ \\
\hline \multirow[t]{2}{*}{ Phytoplankton } & Taxa & Microscopy & Zernova et al. (2000) \\
\hline & Abundances & Calculation & Zernova et al. (2000) \\
\hline \multirow[t]{2}{*}{ Biomarker } & Sterols & Gas chromatography/mass spectrometry & Fahl et al. (2003) \\
\hline & Fatty acids & Gas chromatography & Fahl et al. (2003) \\
\hline
\end{tabular}


Table 3

Daily fluxes of total mass, biogenic and lithogenic matter, opal, carbonate, and POC from September 1995 to August 1996 (given in mg $\mathrm{m}^{-2} \mathrm{~d}^{-1}$ ) and corresponding annual fluxes (given in $\mathrm{g} \mathrm{m}^{-2} \mathrm{y}^{-1}$ ) at $150 \mathrm{~m}$ depth from sediment trap Lomo2 (a), daily fluxes of total mass, biogenic and lithogenic matter, opal, carbonate, and POC (given in $\mathrm{mg} \mathrm{m}^{-2} \mathrm{~d}^{-1}$ ) and corresponding annual fluxes (given in $\mathrm{g} \mathrm{m}^{-2} \mathrm{y}^{-1}$ ) at $1550 \mathrm{~m}$ depth (b), and percentages of the fluxes of total mass flux at $150 \mathrm{~m}$ and $1550 \mathrm{~m}$ depth, respectively (c)

\begin{tabular}{|c|c|c|c|c|c|c|}
\hline & $\begin{array}{l}\text { Total mass } \\
\left(\mathrm{mg} \mathrm{m}^{-2} \mathrm{~d}^{-1}\right)\end{array}$ & $\begin{array}{l}\text { Biogenic } \\
\left(\mathrm{mg} \mathrm{m}^{-2} \mathrm{~d}^{-1}\right)\end{array}$ & $\begin{array}{l}\text { Lithogenic } \\
\left(\mathrm{mg} \mathrm{m}^{-2} \mathrm{~d}^{-1}\right)\end{array}$ & $\begin{array}{l}\text { Opal } \\
\left(\mathrm{mg} \mathrm{m}^{-2} \mathrm{~d}^{-1}\right)\end{array}$ & $\begin{array}{l}\mathrm{CaCO}_{3} \\
\left(\mathrm{mg} \mathrm{m}^{-2} \mathrm{~d}^{-1}\right)\end{array}$ & $\begin{array}{l}\text { POC } \\
\left(\mathrm{mg} \mathrm{m}^{-2} \mathrm{~d}^{-1}\right)\end{array}$ \\
\hline \multicolumn{7}{|l|}{ (a) $150 \mathrm{~m}$} \\
\hline Sept. $95 / 2$ & 127.70 & 45.45 & 82.24 & 30.03 & 4.49 & 5.47 \\
\hline Oct. 95/1 & 13.89 & 5.91 & 7.98 & 2.52 & 0.58 & 1.41 \\
\hline Oct. $95 / 2$ & 3.59 & 2.16 & 1.42 & 0.42 & 1.01 & 0.37 \\
\hline Nov. 95/1 & 5.37 & 3.44 & 1.93 & 1.05 & 0.48 & 0.95 \\
\hline Nov. $95 / 2$ & 3.55 & 2.06 & 1.49 & 0.63 & 0.38 & 0.52 \\
\hline Dec. 95/1 & 2.70 & 1.57 & 1.12 & 0.42 & 0.50 & 0.33 \\
\hline Dec. $95 / 2$ & 4.41 & 2.32 & 2.09 & 0.63 & 0.73 & 0.48 \\
\hline Jan. 96 & 4.68 & 2.89 & 1.79 & 0.84 & 0.69 & 0.68 \\
\hline Feb. 96 & 3.97 & 2.52 & 1.45 & 0.42 & 0.31 & 0.89 \\
\hline March 96/1 & 7.63 & 7.56 & 0.08 & 0.84 & 1.43 & 2.64 \\
\hline March 96/2 & 8.36 & 5.28 & 3.08 & 0.84 & 0.84 & 1.80 \\
\hline April 96/1 & 7.60 & 4.24 & 3.36 & 0.84 & 0.51 & 1.45 \\
\hline April 96/2 & 19.61 & 13.87 & 5.74 & 1.89 & 4.64 & 3.67 \\
\hline May 96/1 & 32.09 & 13.12 & 18.98 & 0.84 & 7.11 & 2.58 \\
\hline May 96/2 & 10.27 & 7.03 & 3.24 & 0.63 & 2.65 & 1.87 \\
\hline June 96/1 & 7.51 & 4.56 & 2.95 & 0.63 & 1.69 & 1.12 \\
\hline June $96 / 2$ & 29.42 & 12.75 & 16.67 & 2.52 & 2.18 & 4.03 \\
\hline July 96/1 & 18.10 & 12.21 & 5.89 & 3.57 & 2.35 & 3.14 \\
\hline July 96/2 & 80.34 & 72.41 & 7.93 & 38.01 & 4.33 & 15.03 \\
\hline Aug. 96/1 & 74.52 & 72.82 & 1.70 & 26.04 & 4.77 & 21.00 \\
\hline Annual flux $\left(\mathrm{g} \mathrm{m}^{-2} \mathrm{y}^{-1}\right)$ & 10.3 & 6.4 & 3.9 & 2.6 & 0.8 & 1.5 \\
\hline \multicolumn{7}{|l|}{ (b) $1550 \mathrm{~m}$} \\
\hline Sept. $95 / 2$ & 209.74 & 53.16 & 156.58 & 32.55 & 4.48 & 8.07 \\
\hline Oct. 95/1 & 225.87 & 52.96 & 172.91 & 32.76 & 3.04 & 8.58 \\
\hline Oct. $95 / 2$ & 139.54 & 33.17 & 106.38 & 22.89 & 1.16 & 4.56 \\
\hline Nov. 95/1 & 33.47 & 8.24 & 25.23 & 4.20 & 1.34 & 1.35 \\
\hline Nov. 95/2 & 12.82 & 3.11 & 9.71 & 1.89 & 0.19 & 0.52 \\
\hline Dec. $95 / 1$ & 5.72 & 1.54 & 4.18 & 0.84 & 0.21 & 0.25 \\
\hline Dec. $95 / 2$ & 7.72 & 1.87 & 5.85 & 1.05 & 0.16 & 0.33 \\
\hline Jan. 96 & 12.90 & 3.92 & 8.98 & 1.89 & 0.94 & 0.55 \\
\hline Feb. 96 & 8.50 & 2.52 & 5.98 & 1.26 & 0.09 & 0.58 \\
\hline March 96/1 & 16.41 & 3.98 & 12.43 & 2.52 & 0.43 & 0.51 \\
\hline March 96/2 & 16.55 & 4.30 & 12.25 & 2.52 & 0.37 & 0.70 \\
\hline
\end{tabular}


Table 3 (continued)

\begin{tabular}{|c|c|c|c|c|c|c|c|c|}
\hline & & $\begin{array}{l}\text { Total mass } \\
\left(\mathrm{mg} \mathrm{m}^{-2} \mathrm{~d}^{-1}\right)\end{array}$ & $\begin{array}{l}\text { Biogenic } \\
\left(\mathrm{mg} \mathrm{m}^{-2} \mathrm{~d}^{-1}\right)\end{array}$ & $\begin{array}{l}\text { Lithogenic } \\
\left(\mathrm{mg} \mathrm{m}^{-2} \mathrm{~d}^{-1}\right)\end{array}$ & \multicolumn{2}{|l|}{$\begin{array}{l}\text { Opal } \\
\left(\mathrm{mg} \mathrm{m}^{-2} \mathrm{~d}^{-1}\right)\end{array}$} & $\begin{array}{l}\mathrm{CaCO}_{3} \\
\left(\mathrm{mg} \mathrm{m}^{-2} \mathrm{~d}^{-1}\right)\end{array}$ & $\begin{array}{l}\text { POC } \\
\left(\mathrm{mg} \mathrm{m}^{-2} \mathrm{~d}^{-1}\right)\end{array}$ \\
\hline April 96/1 & & 8.07 & 2.25 & 5.82 & 1.26 & & 0.24 & 0.38 \\
\hline April 96/2 & & 6.03 & 2.03 & 4.00 & 0.84 & & 0.66 & 0.26 \\
\hline May 96/1 & & 8.26 & 2.44 & 5.83 & 1.05 & & 0.70 & 0.34 \\
\hline May $96 / 2$ & & 6.76 & 2.26 & 4.50 & 0.84 & & 0.75 & 0.34 \\
\hline June 96/1 & & 6.04 & 1.71 & 4.33 & 0.84 & & 0.31 & 0.28 \\
\hline June $96 / 2$ & & 20.34 & 4.01 & 16.33 & 1.89 & & 0.67 & 0.73 \\
\hline July 96/1 & & 17.41 & 11.45 & 5.96 & 1.47 & & 2.39 & 3.80 \\
\hline July 96/2 & & 37.25 & 35.94 & 1.31 & 17.01 & & 2.85 & 8.04 \\
\hline Aug. 96/1 & & 33.62 & 33.06 & 0.56 & 10.71 & & 3.53 & 9.41 \\
\hline Annual flux & $\left.\mathrm{y}^{-1}\right)$ & 16.7 & 5.5 & 11.3 & 2.9 & & 0.5 & 1.05 \\
\hline \multirow[t]{2}{*}{ (c) } & \multicolumn{4}{|l|}{$150 \mathrm{~m}$} & \multicolumn{4}{|l|}{$1550 \mathrm{~m}$} \\
\hline & $\begin{array}{l}\text { Lithogenic flux } \\
(\%)\end{array}$ & $\begin{array}{l}\text { Opal flux } \\
(\%)\end{array}$ & $\begin{array}{l}\mathrm{CaCO}_{3} \text { flux } \\
(\%)\end{array}$ & $\begin{array}{l}\text { POC flux } \\
(\%)\end{array}$ & $\begin{array}{l}\text { Lithogenic flux } \\
(\%)\end{array}$ & $\begin{array}{l}\text { Opal flux } \\
(\%)\end{array}$ & $\begin{array}{l}\mathrm{CaCO}_{3} \text { flux } \\
(\%)\end{array}$ & $\begin{array}{l}\text { POC flux } \\
(\%)\end{array}$ \\
\hline Sept. 95/2 & 64.4 & 23.5 & 3.5 & 4.3 & 74.7 & 15.5 & 2.1 & 3.9 \\
\hline Oct. $95 / 1$ & 57.5 & 18.1 & 4.2 & 10.1 & 76.6 & 14.5 & 1.3 & 3.8 \\
\hline Oct. $95 / 2$ & 39.7 & 11.7 & 28.0 & 10.3 & 76.2 & 16.4 & 0.8 & 3.3 \\
\hline Nov. $95 / 1$ & 36.0 & 19.6 & 8.9 & 17.8 & 75.4 & 12.6 & 4.0 & 4.0 \\
\hline Nov. $95 / 2$ & 42.0 & 17.8 & 10.8 & 14.7 & 75.7 & 14.8 & 1.5 & 4.0 \\
\hline Dec. $95 / 1$ & 41.7 & 15.6 & 18.4 & 12.2 & 73.2 & 14.7 & 3.6 & 4.3 \\
\hline Dec. $95 / 2$ & 47.4 & 14.3 & 16.5 & 10.9 & 75.8 & 13.6 & 2.0 & 4.3 \\
\hline Jan. 96 & 38.3 & 18.0 & 14.7 & 14.5 & 69.6 & 14.7 & 7.3 & 4.2 \\
\hline Feb. 96 & 36.5 & 10.6 & 7.9 & 22.5 & 70.3 & 14.8 & 1.1 & 6.9 \\
\hline March 96/1 & 1.0 & 11.0 & 18.8 & 34.6 & 75.8 & 15.4 & 2.6 & 3.1 \\
\hline March 96/2 & 36.9 & 10.1 & 10.0 & 21.5 & 74.0 & 15.2 & 2.2 & 4.2 \\
\hline April 96/1 & 44.2 & 11.1 & 6.6 & 19.0 & 72.1 & 15.6 & 3.0 & 4.7 \\
\hline April 96/2 & 29.3 & 9.6 & 23.6 & 18.7 & 66.4 & 13.9 & 11.0 & 4.4 \\
\hline May 96/1 & 59.1 & 2.6 & 22.2 & 8.0 & 70.5 & 12.7 & 8.5 & 4.1 \\
\hline May 96/2 & 31.6 & 6.1 & 25.8 & 18.3 & 66.5 & 12.4 & 11.0 & 5.0 \\
\hline June $96 / 1$ & 39.3 & 8.4 & 22.5 & 14.9 & 71.8 & 13.9 & 5.2 & 4.6 \\
\hline June $96 / 2$ & 56.7 & 8.6 & 7.4 & 13.7 & 80.3 & 9.3 & 3.3 & 3.6 \\
\hline July 96/1 & 32.6 & 19.7 & 13.0 & 17.4 & 34.2 & 8.4 & 13.7 & 21.8 \\
\hline July $96 / 2$ & 9.9 & 47.3 & 5.4 & 18.7 & 3.5 & 45.7 & 7.7 & 21.6 \\
\hline Aug. 96/1 & 2.3 & 34.9 & 6.4 & 28.2 & 1.7 & 31.9 & 10.5 & 28.0 \\
\hline
\end{tabular}

Note: Biogenic matter $=2 \times \mathrm{POC}+\mathrm{CaCO}_{3}+$ Opal, see Table 2. 


\subsection{Annual fluxes}

Annual fluxes of lithogenic matter, $\mathrm{CaCO}_{3}$, opal, and POC were 3.9, 0.8, 2.6 and $1.5 \mathrm{~g} \mathrm{~m}^{-2} \mathrm{y}^{-1}$, respectively, at $150 \mathrm{~m}$ and $11.3,0.5$ and 2.9 , $1.05 \mathrm{~g} \mathrm{~m}^{-2} \mathrm{y}^{-1}$, respectively, at $1550 \mathrm{~m}$ (Table 3), indicating a clear dominance of lithogenic matter in both traps. The lithogenic character of the sedimentary material is pronounced in the entire central Arctic Ocean and is due to the high input of terrigenous matter by the Eurasian and Amerasian rivers and the relatively low primary production. Because of the restricted "growth period," the food web is highly developed; most of the carbon produced by the phytoplankton is effectively grazed down by zooplankton. Detritus and faeces are also effectively recycled in the upper water column (Grahl et al., 1999). Carbonate is of minor importance, as documented in the Laptev Sea and Lomonosov Ridge sediments, where carbonate contents are between 0 and 3 and $<10 \%$, respectively (Stein et al., 1994; Stein, 1996). In summary, the central Arctic Ocean seems to be a "terrigenous, low-productivity ocean."

The flux of organic carbon on the Lomonosov Ridge is similar to the fluxes found in the seasonally ice-covered Greenland Sea (Noji et al., 2001; Peinert et al., 2001; Peinert and Noji, 2004) but up to nine times lower than fluxes determined in the southern Kara (Gaye et al., submitted) and Beaufort Seas (Moran, 2004; O'Brien et al., 2006). The latter fluxes are large because of the river discharge in these regions (Table 5). In the permanently ice-covered, very low-productivity region north of the Canadian Archipelago, the lowest vertical flux values ever measured in the ocean were found in sediment traps deployed from large ice floes ("Canadian Ice Islands") (Hargrave, 2004; Table 5). Flux values obtained from the western part of the Weddell Sea (Antarctic) are 10 times higher than those determined on the Lomonosov Ridge (Fischer et al., 2003; Table 5).

\subsection{Seasonal variability}

Our data from the long-term sediment traps representing the time interval from September 1995 to August 1996 reflect seasonality in all measured and calculated parameters. We can distinguish three different periods during the year: first, a period characterized by low productivity, low fluxes and extensive sea-ice cover (second half of NovemberMarch; Winter phase); second, a period characterized by ice-melting, ice-free conditions and high biogenic matter flux (April-August; Biogenic phase); and third, a period characterized by ice-free conditions and highest lithogenic matter flux (September-end of October; Lithogenic phase). These characteristics are obvious in both the shallow $(150 \mathrm{~m})$ and the deep $(1550 \mathrm{~m})$ trap, although flux values and particle composition are somewhat different in the two traps.

\subsubsection{Winter phase (second half of November- March)}

In general, the fluxes are fairly low at both 150 and $1550 \mathrm{~m}$ depth during the ice-covered winter months. The average total mass flux is less than $10 \mathrm{mg} \mathrm{m}^{-2} \mathrm{~d}^{-1}$, with POC, opal and $\mathrm{CaCO}_{3}$ fluxes $<2 \mathrm{mg} \mathrm{m}^{-2} \mathrm{~d}^{-1}$ (averages calculated from Table 3). The average lithogenic proportion is much higher at $1550 \mathrm{~m}\left(8.5 \mathrm{mg} \mathrm{m}^{-2} \mathrm{~d}^{-1} ; 74 \%\right.$ of total mass flux) than at $150 \mathrm{~m}\left(1.6 \mathrm{mg} \mathrm{m}^{-2} \mathrm{~d}^{-1} ; 31 \%\right.$ of total mass flux) water depth, suggesting an additional, lateral input at $1550 \mathrm{~m}$. The existence of the lateral input is also supported by the downward-increasing fluxes of the land-derived terrigenous biomarkers campesterol and $\beta$-sitosterol (Tables 4 and 5). The fluxes of POC and the relatively labile fatty acids, on the other hand, are lower in the deep trap because of degradation. The typical fast degradation of the lipid compounds, which are labile because their molecular structures include one or more double bonds (here the monounsaturated fatty acids $\mathrm{C}_{16: 1(n-7)}$ and $\mathrm{C}_{16: 1(n-5)}$, and the polyunsaturated $\mathrm{C}_{20: 5(n-3)}$ fatty acid), is also described by Wakeham et al. (1997) for sedimentary records from the Pacific.

Microscopic investigation of the trapped material shows mostly detritus agglomerates containing diatoms, debris and empty valves of the diatoms Fragilariopsis oceanica, Melosira arctica, Nitzschia frigida, and Chaetoceros radiatus. C. radiatus is frequently predominant in the shallow trap at $150 \mathrm{~m}$ depth (Zernova et al., 2000). C. radiatus and Chaetoceros furcellatus and Chaetoceros resting spores were probably entrained into the sea ice during its formation on the Laptev Sea shelf and transported with the Transpolar Drift to the Lomonosov Ridge. The other above-mentioned diatom species are thought to belong to the subice communities or to be pelagic (Table 6, Zernova et al., 2000).

In general, we found a typical winter situation from the end of November to March due to the permanent sea-ice cover and light limitation. For 
Table 4

Daily fluxes of the sum of campesterol and $\beta$-sitosterol and the sum of $\mathrm{C}_{16: 1(n-7)}, \mathrm{C}_{16: 1(n-5)}$, and $\mathrm{C}_{20: 5(n-3)}$ from September 1995 to August 1996 (given in $\mu \mathrm{g} \mathrm{m}^{-2} \mathrm{~d}^{-1}$ ) and corresponding annual fluxes (given in $\mathrm{mg} \mathrm{m}^{-2} \mathrm{y}^{-1}$ ) in $150 \mathrm{~m}$ and $1550 \mathrm{~m}$ sediment traps at Lomo2

\begin{tabular}{|c|c|c|c|c|}
\hline & $\begin{array}{l}150 \mathrm{~m} \\
\text { Campesterol }+\beta \text {-sitosterol } \\
\left(\mu \mathrm{g} \mathrm{m}^{-2} \mathrm{~d}^{-1}\right)\end{array}$ & $\begin{array}{l}C_{16: 1}+C_{20: 5} \text { fatty acids } \\
\left(\mu \mathrm{g} \mathrm{m}^{-2} \mathrm{~d}^{-1}\right)\end{array}$ & $\begin{array}{l}1550 \mathrm{~m} \\
\text { Campesterol }+\beta \text {-sitosterol } \\
\left(\mu \mathrm{g} \mathrm{m}^{-2} \mathrm{~d}^{-1}\right)\end{array}$ & $\begin{array}{l}\mathrm{C}_{16: 1}+\mathrm{C}_{20: 5} \text { fatty acids } \\
\left(\mu \mathrm{g} \mathrm{m}^{-2} \mathrm{~d}^{-1}\right)\end{array}$ \\
\hline Sept. 95/2 & 321.75 & 466.42 & 499.54 & 281.62 \\
\hline Oct. 95/1 & 89.96 & 52.02 & 1662.35 & 271.02 \\
\hline Oct. $95 / 2$ & 16.89 & 50.11 & 1021.71 & 160.49 \\
\hline Nov. 95/1 & 21.62 & 373.95 & 155.09 & 40.93 \\
\hline Nov. $95 / 2$ & 19.18 & 222.42 & 75.04 & 37.98 \\
\hline Dec. $95 / 1$ & 16.44 & 260.26 & 56.16 & 25.00 \\
\hline Dec. $95 / 2$ & 23.12 & 232.57 & 54.22 & 21.73 \\
\hline Jan. 96 & 22.82 & 125.80 & 88.49 & 76.70 \\
\hline Feb. 96 & 17.40 & 376.69 & 55.52 & 85.05 \\
\hline March 96/1 & 4.22 & 126.92 & 400.67 & 15.85 \\
\hline March 96/2 & 30.99 & 785.90 & 96.77 & 55.33 \\
\hline April 96/1 & 30.22 & 541.79 & 36.96 & 37.31 \\
\hline April 96/2 & 49.88 & 524.67 & 32.10 & 24.28 \\
\hline May 96/1 & 152.08 & 1028.37 & 32.68 & 42.37 \\
\hline May 96/2 & 28.99 & 398.84 & 30.27 & 33.21 \\
\hline June 96/1 & 24.10 & 356.04 & 28.85 & 35.43 \\
\hline June 96/2 & 115.79 & 842.93 & 83.36 & 60.32 \\
\hline July 96/1 & 50.90 & 853.67 & 28.46 & 1420.67 \\
\hline July $96 / 2$ & 53.31 & 1527.08 & 5.14 & 1006.97 \\
\hline Aug. 96/1 & 21.75 & 4835.51 & 5.82 & 2147.87 \\
\hline Annual flux $\left(\mathrm{mg} \mathrm{m}^{-2} \mathrm{y}^{-1}\right)$ & 22.6 & 304.4 & 77.7 & 130.5 \\
\hline
\end{tabular}

Table 5

Particulate organic carbon (POC) fluxes and primary production (both given in in $\mathrm{g} \mathrm{m}^{-2} \mathrm{y}^{-1}$ ) at other Arctic regions and other ocean areas in comparison to out data from the Lomonosov Ridge, where (a) is normalized to $133 \mathrm{~m}$ depth (according to Schlitzer, 2002), (b) data from Sakshaug (2004), (c) calculated after Boetius and Damm (1998)

\begin{tabular}{|c|c|c|c|c|c|c|c|}
\hline Site & Region & Position & $\begin{array}{l}\text { Depth of } \\
\text { trap } \\
\text { (m) }\end{array}$ & $\begin{array}{l}\text { Time } \\
\text { (month) }\end{array}$ & $\begin{array}{l}\text { Vertical POC } \\
\text { flux } \\
\left(\mathrm{gC} \mathrm{m}^{-2} \mathrm{y}^{-1}\right)\end{array}$ & $\begin{array}{l}\text { Primary } \\
\text { production } \\
\left(\mathrm{gC} \mathrm{m}^{-2} \mathrm{y}^{-1}\right)\end{array}$ & Reference \\
\hline WS1 & Weddell Sea & $62.4^{\circ} \mathrm{S}, 34.8^{\circ} \mathrm{W}$ & $133^{\mathrm{a}}$ & 12 & 14 & 84 & Fischer et al. (2003) \\
\hline WR1 & SW Africa & $20.1^{\circ} \mathrm{S}, 9.2^{\circ} \mathrm{E}$ & $133^{\mathrm{a}}$ & 12 & 68 & 328 & Fischer et al. (2003) \\
\hline NEW & Fram Strait & $80^{\circ} \mathrm{N}, 11^{\circ} \mathrm{W}$ & 130 & 11 & 1.0 & $20-50^{\mathrm{b}}$ & Bauerfeind (2004) \\
\hline $\mathrm{KS}$ & Kara Sea & $74^{\circ} \mathrm{N}, 80^{\circ} \mathrm{W}$ & 36 & 12 & 9.8 & $30-5^{\mathrm{b}}$ & Gaye et al., 2007 \\
\hline SS-4 & Beaufort Sea & $69.9^{\circ} \mathrm{N}, 138.5^{\circ} \mathrm{W}$ & 200 & 12 & 6 & $30-70^{\mathrm{b}}$ & O'Brien et al. (2006) \\
\hline CII & Canadian Ice Island & $81^{\circ} \mathrm{N}, 96^{\circ} \mathrm{W}$ & 100 & 9 & 0.07 & - & Hargrave (2004) \\
\hline Lomo2 & Lomonosov Ridge & $81^{\circ} \mathrm{N}, 139^{\circ} \mathrm{E}$ & 150 & 11 & 1.5 & $18^{\mathrm{c}}$ & This paper \\
\hline Lomo2 & Lomonosov Ridge & $81^{\circ} \mathrm{N}, 139^{\circ} \mathrm{E}$ & 1550 & 11 & 1.05 & $18^{\mathrm{c}}$ & This paper \\
\hline
\end{tabular}

other Arctic regions the winter season occurs approximately within the same time period (Bauerfeind, 2004). In the Fram Strait, for example, freshly produced material was present in trap material during March/April (Bauerfeind, 2004), whereas in the Kara Sea the fluxes increased some weeks later in April/May with the first break-up of the ice cover and polynya formation (Gaye et al., submitted).
Focusing in detail on the time interval April/May, it becomes obvious that the pronounced growth period of phytoplankton starts some time later on the Lomonosov Ridge (see Section 3.2.2). That means that the ice edge and primary production fluctuate widely in the Arctic Ocean in response to seasonal and regional changes in wind, ice production, sea-surface temperature and insolation. 
Table 6

Dominant diatom composition during different phases during the year (after Zernova et al., 2000 and Nöthig unpubl. data, 1996)

\begin{tabular}{lllll}
\hline Growth phases & $\begin{array}{l}\text { Cells containing } \\
\text { chloroplasts }\end{array}$ & $\begin{array}{l}\text { Sub-ice algal community; } \\
\text { Nitzschia frigida, N. promare, } \\
\text { Gyrosigma } \text { spec., Melosira } \\
\text { arctica }\end{array}$ & $\begin{array}{l}\text { Pelagic/ice more open } \\
\text { ocean; Fragilariopsis } \\
\text { oceanica }\end{array}$ & $\begin{array}{l}\text { Pelagic more shelf- } \\
\text { associated; } \\
\text { Chaetoceros spp } \\
\text { resting spores }\end{array}$ \\
\hline $\begin{array}{l}\text { Winter phase } \\
\text { Biogenic phase }\end{array}$ & $<5 \%$ & + & + & ++ \\
$\begin{array}{l}\text { Early (April/May) } \\
\text { Late (June-Aug.) }\end{array}$ & About 5\% & Rare & + & +++ \\
Lithogenic phase & $<10 \%$ & +++ & +++ & + \\
\hline
\end{tabular}

One cross $(+)$ indicates common with many empty valves, two crosses $(++)$ indicate abundant, and three crosses $(+++)$ indicate abundant in high cell numbers with intact cells.

\subsubsection{Biogenic phase (April-August)}

From April to August the fluxes continuously increased. Average total mass fluxes were $31 \mathrm{mg} \mathrm{m}^{-2} \mathrm{~d}^{-1}$ at $150 \mathrm{~m}$ and $16 \mathrm{mg} \mathrm{m}^{-2} \mathrm{~d}^{-1}$ at $1550 \mathrm{~m}$ depth (Table 3). The composition of sedimenting particles shows a dominance of biogenic matter with 24 and $11 \mathrm{mg} \mathrm{m}^{-2} \mathrm{~d}^{-1}(76 \%$ and $66 \%$ of total mass flux) for the shallow and deep traps, respectively. The lithogenic fluxes are very similar at both depths ( 7 and $6 \mathrm{mg} \mathrm{m}^{-2} \mathrm{~d}^{-1}$ ). The low lithogenic proportion of the sedimentary material correlates with the very low fluxes of the land-derived biomarkers campesterol and $\beta$-sitosterol (Table 4). The average POC fluxes are 6 and $2.5 \mathrm{mg} \mathrm{m}^{-2} \mathrm{~d}^{-1}$ at 150 and $1550 \mathrm{~m}$ water depth, respectively. Opal fluxes decrease downwards from 8.3 to $4 \mathrm{mg} \mathrm{m}^{-2} \mathrm{~d}^{-1}$ (Table 3 ). These decreasing opal fluxes are probably caused by dissolution (see below).

The start of algal growth occurs at the end of April to the beginning of May, dominated by the ice-associated Nitzschia species although in low abundances (Zernova et al., 2000). This early start of algal growth under sea-ice cover was also noted for the Laptev Sea by Okolodkov (1992), who related it to the slightly increasing insolation. Increasing diatom fluxes occur from the beginning of June, dominated by pennate diatoms ( $N$. frigida, Nitzschia promarae, $F$. oceanica, Gyrosigma stuxbergii), until the end of July, with centric and pennate species ( $M$. arctica, $F$. oceanica) (Zernova et al., 2000). The highest summer peak in August is caused by the pennate diatoms $F$. oceanica and $N$. frigida (Table 6). The high abundances of diatoms at $150 \mathrm{~m}$ depth during July/August is supported by the high fluxes of the diatom-specific fatty acids and opal. The latter reaches values up to $40 \mathrm{mg} \mathrm{m}^{-2} \mathrm{~d}^{-1}$, which is almost $50 \%$ of the total mass flux during these weeks (Tables 3 and 4).

In general, the time interval from April to August is characterized by a high biogenic proportion. Lithogenic material derived from melting sea ice is of minor importance. The marine organic matter (here POC and fatty acids) undergoes degradation from 150 to $1550 \mathrm{~m}$ depth. Opal is partly dissolved during its sinking to the sea floor. This is also supported by the comparison of our trap data with surface sediment data from Lomonosov Ridge close to the trap location. Based on an opal content of $2 \%$ (Nürnberg, 1996) and the accumulation rate of total sediment (48 $\mathrm{g} \mathrm{m}^{-2} \mathrm{y}^{-1}$; Stein et al., 2001), opal accumulation rate is $0.96 \mathrm{~g} \mathrm{~m}^{-2} \mathrm{y}^{-1}$. The annual opal flux determined at $1550 \mathrm{~m}$ depth, on the other hand, is $2.9 \mathrm{~g} \mathrm{~m}^{-2} \mathrm{y}^{-1}$ (Table 3). According to Heiskanen and Keck (1996) and Nürnberg (1996), opal contents in the surface sediment decrease from the Lena River in the direction of the Lomonosov Ridge, supporting our assumption that the downward decrease in opal fluxes is caused by dissolution.

\subsubsection{Lithogenic phase (September-end of October)}

From September to the end of October, the highest total mass fluxes were $130 \mathrm{mg} \mathrm{m}^{-2} \mathrm{~d}^{-1}$ at $150 \mathrm{~m}$ and $230 \mathrm{mg} \mathrm{m}^{-2} \mathrm{~d}^{-1}$ at $1550 \mathrm{~m}$ depth (Table 3). The composition shows a dominance of lithogenic matter, with 31 and $145 \mathrm{mg} \mathrm{m}^{-2} \mathrm{~d}^{-1}$ (54\% and $75 \%$ of total mass flux) for the shallow and the deep trap, respectively (Table 3). This is also supported by the terrigenous biomarkers campesterol and $\beta$-sitosterol. The highest fluxes of these land-derived components occur during 
these months (up to 320 and $1600 \mathrm{mg} \mathrm{m}^{-2} \mathrm{~d}^{-1}$ at 150 and $1550 \mathrm{~m}$, respectively; Table 4). The good correlation between the biomarker and the lithogenic matter fluxes at both depths is shown in Figs. $4 \mathrm{a}$ and $\mathrm{b}$. In general, the fluxes at $1550 \mathrm{~m}$ depth are distinctly higher than at $150 \mathrm{~m}$ depth. This is also true for most of the biogenic compounds (see Figs. 2b, d, 3, Table 3 and 4). Average daily fluxes of POC and opal are $6 \mathrm{mg} \mathrm{m}^{-2} \mathrm{~d}^{-1}$ and $11 \mathrm{mg} \mathrm{m}^{-2} \mathrm{~d}^{-1}$, respectively, at the shallow trap and $8 \mathrm{mg} \mathrm{m}^{-2} \mathrm{~d}^{-1}$ and $30 \mathrm{mg} \mathrm{m}^{-2} \mathrm{~d}^{-1}$, respectively, at the deep trap. The $\mathrm{CaCO}_{3}$ fluxes at both depths, on the other hand, are similar ( 2 and $2.6 \mathrm{mg} \mathrm{m}^{-2} \mathrm{~d}^{-1}$ for the shallow and deep trap, respectively; Table 3), suggesting no carbonate dissolution with depth. This is in agreement with results of investigations of carbonate dissolution on planktonic foraminifera tests from the eastern central Arctic Ocean (Pagels, 1991). Based on these results, the modern lysocline of this area is at about $4700 \mathrm{~m}$ water depth, and carbonate dissolution seems to be negligible in shallow depths.

In summary, the terrigenous character (see Figs. 2a and 3a) of the material transported downward to the sea floor during these ice-free months is clearly pronounced. The biological production is of only minor importance during this time as, also supported by the microscopic data, which show mostly empty diatom valves at both depths (Zernova et al., 2000; Nöthig unpubl. data, 1996). These valves cause the relatively high opal fluxes (Fig. 2b), especially at $150 \mathrm{~m}$ depth, where the cells without chloroplasts were dominated by $M$. arctica and with chloroplasts by F. oceanica (Zernova et al., 2000; Table 6).
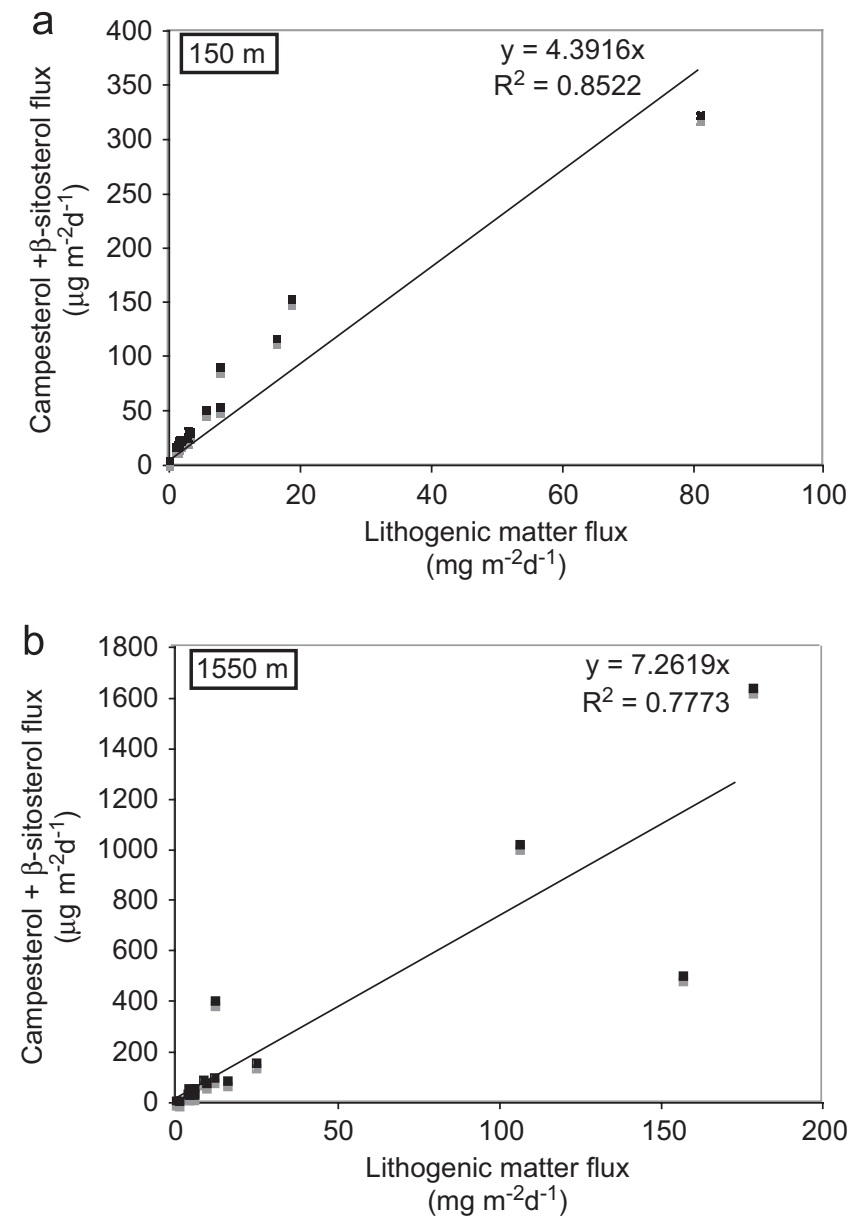

Fig. 4. Correlation between lithogenic matter flux (given in $\mathrm{mg} \mathrm{m}^{-2} \mathrm{~d}^{-1}$ ) and sum of campesterol and $\beta$-sitosterol (given in $\mu \mathrm{g} \mathrm{m}{ }^{-2} \mathrm{~d}^{-1}$ ) from September 1995 to August 1996 at $150 \mathrm{~m}$ (a) and $1550 \mathrm{~m}$ (b) depth. 


\subsubsection{Source and transport of the lithogenic matter}

A remaining question is the source the trapped terrigenous material. Focusing on $150 \mathrm{~m}$ depth we assume that the terrigenous particulate organic material derived from the Laptev Sea shelf (with the Lena River as a dominant source), was transported with sea ice by the Transpolar Drift to the Lomonosov Ridge. In general, the sea ice is an important transport mechanism for terrigenous organic carbon (see Section 3.1), but we have to consider that only $6 \%\left(0.18 \times 10^{6} \mathrm{t}\right.$, Eicken, 2004) of the annual terrigenous POC input $\left(2.74 \times 10^{6} \mathrm{t}\right.$, where more than $70 \%$ is supplied by the Lena River; Rachold et al., 2004) is a sea-ice-associated transport from the Laptev Sea into the Arctic Ocean, whereas $30 \%$ of the input is supplied towards the interior ocean via currents, including turbidity currents (Stein and Fahl, 2004).

We now consider the possibility that the terrigenous material that is trapped at $150 \mathrm{~m}$ comes from ice melting in September/October can be related to the high Lena River discharge in June (Fig. 1). Because of the patchy ice conditions on the Laptev Sea shelf, greatly differing values for the ice velocity have been reported (Colony and Thorndike, 1984; Eicken et al., 1997; Rigor and Colony, 1997; Eicken et al., 2000; Martin and Augstein, 2000), but $0.1 \mathrm{~m} / \mathrm{s}$ seems to be a reasonable estimate (Haas, pers. commun., 2006). Using this velocity and a distance to the Lomonosov Ridge of about $850 \mathrm{~km}$, the sea-ice-associated sediments would reach the investigation area in about 3 months. This is only a rough estimate, but it seems to explain the correlation between the high terrigenous flux in the traps in September/October and the high Lena River discharge in June. Because sea ice is only one transport mechanism for the fluvial material, with only $6 \%$ of the annual terrigenous POC from the Laptev Sea being transported northward via sea ice (Eicken, 2004), we conclude that ocean currents are responsible for the transport as well. This is supported by several investigations in the Kara Sea showing that $>50 \%$ fluvially derived organic carbon could be detected even in surface sediments from the central and northern Kara Sea, i.e., far away $(>600 \mathrm{~km})$ from the coast and river mouths (e.g., Krishnamurthy et al., 2001; Stein and Fahl, 2004). We have to consider, however, that no fluvially derived diatoms could be determined in the traps. This fact is supported by the Kara Sea investigation where fluvially derived diatom cells in the southern part off the Yenisey were empty or destroyed when entering the saline water (Gaye et al., submitted).

The major importance of terrigenous sediment input from the Laptev Sea for sediment accumulation on the Lomonosov Ridge is also supported on geological time scales (Stein et al, 1994, 2001, 2004; Darby et al., 1997; Nørgaard-Pedersen et al., 1998). Sedimentation rates from Late Quarternary sediments decrease from $5 \mathrm{~cm} \mathrm{ky}^{-1}$ on the Lomonosov Ridge close to the Eurasian continental margin to $0.7 \mathrm{~cm} \mathrm{ky}^{-1}$ near the North Pole (Stein et al, 1994, 2001), following the route of the Transpolar Drift as an important source of dirty sea ice. Based on geophysical data the thickness of the sediment cover decreases from the south to the north of the Lomonosov Ridge indicating the importance of terrigenous input even throughout the Tertiary (Jokat, 2005). In addition, mineralogical data support the transport of material from the Laptev Sea via sea ice to the Lomonosov Ridge. In this context heavy minerals seem to be a good tracer because they cannot be transported via ocean currents over such a long distance (Stein and Korolev, 1994; Behrends et al., 1999). High contents of the heavy mineral amphibole derived from the Lena River hinterland, and pyroxene originating from the Putoran Mountains, were found on the Lomonosov Ridge. Sediment transport by turbidity currents, which are important in the deep basins of the Arctic Ocean, is not thought to be important on the Lomonosov Ridge (Stein et al., 2004).

At $1550 \mathrm{~m}$ depth the source of the trapped material seems to be different. The order-of-magnitude higher total mass flux values (Figs. 2a and 3a), correlating with high lithogenic fluxes (Table 3 ) and land-derived sterol fluxes (Table 4), point to a strong influence of lateral transport at the deep trap. The most probable transport is related to the Atlantic and intermediate water layers, which may carry material from the Barents and Kara Seas along the Eurasian continental margins and recirculate northwards to the Amundsen Basin, passing the trap position (Rudels et al., 2000). Additional transport of material to the trap position within a benthic nepheloid layer (BNL), which may extend several hundred meters above the seafloor (Rutgers van der Loeff et al., 2002), and local resuspension cannot be excluded. The BNL is maintained by fine particles (e.g., clay minerals), which can be transported over very long distances (Rutgers van der Loeff et al., 2002). Unfortunately, no data on 
Table 7

Basics and results from the calculation of the proportion of lateral terrigenous organic carbon flux and lateral lithogenic matter flux including data from (a) Stein et al. (2001), (b) Boucsein and Stein (2000), (c) calculated according to Betzer et al. (1984) with primary production of $18 \mathrm{~g} \mathrm{Cm}^{-2} \mathrm{y}^{-1}$ after Boetius and Damm (1998), and (e) Stein et al., 2004. Betzer et al. (1984) formula: Carbon flux $=0.409 \times$ depth $^{-0.63}$ surface water productivity ${ }^{1.41}$

\begin{tabular}{|c|c|c|c|c|c|c|c|}
\hline Depth & $\begin{array}{l}\text { Lithogenic } \\
\text { flux } \\
\left(\mathrm{gC} \mathrm{m}^{-2} \mathrm{y}^{-1}\right)\end{array}$ & $\begin{array}{l}\text { Lateral } \\
\text { (based on } \\
\text { lith. flux) } \\
\left(\mathrm{gC} \mathrm{m}^{-2} \mathrm{y}^{-1}\right)\end{array}$ & $\begin{array}{l}\text { POC flux } \\
\left(\mathrm{gC} \mathrm{m}^{-2} \mathrm{y}^{-1}\right)\end{array}$ & $\begin{array}{l}\text { Marine } \\
\text { Maceral }\end{array}$ & $\begin{array}{l}\text { Vertical } \\
\text { Marine } \\
\text { POCflux } \\
\left(\mathrm{gC} \mathrm{m}^{-2} \mathrm{y}^{-1}\right)\end{array}$ & $\begin{array}{l}\text { Vertical } \\
\text { terrigenous POC } \\
\text { flux } \\
\left(\mathrm{gC} \mathrm{m}^{-2} \mathrm{y}^{-1}\right)\end{array}$ & $\begin{array}{l}\text { Lateral } \\
\text { terrigenous } \\
\text { (based on } \\
\text { OC) } \\
\left(\mathrm{gC} \mathrm{m}^{-2} \mathrm{y}^{-1}\right)\end{array}$ \\
\hline \multirow{3}{*}{$\begin{array}{l}150 \\
1550\end{array}$} & 3.9 & $?$ & 1.5 & - & $1.03^{\mathrm{c}}$ & $0.47^{\mathrm{d}}$ & $?$ \\
\hline & 11.3 & $7.4(65 \%)^{*}$ & 1.05 & - & $0.24^{\mathrm{c}}$ & $0.47^{\mathrm{d}}$ (total: 0.81 ) & $0.34(42 \%)$ \\
\hline & $\begin{array}{l}\text { AR of total } \\
\text { sediment } \\
\left(\mathrm{gC} \mathrm{m}^{-2} \mathrm{y}^{-1}\right)\end{array}$ & $\begin{array}{l}\text { Additional } \\
\text { lateral input } \\
\text { (into the } \\
\text { sediment) } \\
\left(\mathrm{gC} \mathrm{m}^{-2} \mathrm{y}^{-1}\right)\end{array}$ & $\begin{array}{l}\text { Accumulation } \\
\text { rate (AR) }\end{array}$ & $\begin{array}{l}\text { Marine } \\
\text { Maceral }\end{array}$ & $\left(\mathrm{gC} \mathrm{m}^{-2} \mathrm{y}^{-1}\right)$ & Terrigenous AR & \\
\hline 1712 & $48^{\mathrm{e}}$ & 30 & $0.3^{\mathrm{a}}$ & $25^{\mathrm{b}}$ & 0.07 & 0.23 & \\
\hline
\end{tabular}

${ }^{\mathrm{d}}$ Calculated with no degradation of terrigenous organic compounds.

*Under the assumption that $3.9 \mathrm{gC} \mathrm{m}^{-2} \mathrm{y}^{-1}$ is vertically transported.

the existence of a BNL at the trap location are available.

To estimate the importance of lateral transport we estimate the portion of the laterally transported lithogenic fraction and terrigenous organic carbon fraction (see Table 7). First we calculate the lateral proportion of flux based on the lithogenic flux data (Table 7). This results in a lateral transport of lithogenic material of $65 \%$. Second, using the primary production according to Boetius and Damm (1998), the depth-dependent degradation of marine organic carbon after Betzer et al. (1984), and the measured POC flux in the trap (Table 7), we calculate the terrigenous organic carbon proportion. At the shallow trap, we do not know the exact amount of lateral transport. The relatively high proportion of terrigenous material $\left(0.47 \mathrm{~g} \mathrm{C} \mathrm{m}^{-2} \mathrm{y}^{-1}\right.$ or $30 \%$ of the total POC flux) cannot be explained just by melting of the sediment-laden sea ice at the trap position, because only $6 \%$ of the terrigenous POC from the Laptev Sea is from sea-ice-associated transport (Eicken, 2004). The quite high input of terrigenous matter at $150 \mathrm{~m}$, however, could be caused by the release of ice-rafted sediments taking place in other regions and then lateral transport to the trap location by currents (Trimble et al., 2004; Baskaran, 2005).

At $1550 \mathrm{~m}$ depth we calculated the terrigenous carbon flux under the assumption that there is no degradation of the terrigenous organic carbon. This seems to be realistic because long-distance transport of material from the source (here the Laptev Sea shelf) has been found, suggesting that only the more stable terrigenous fraction reaches the Lomonosov Ridge (for discussion of degradation of terrigenous organic matter, see Ittekkot, 1988). This calculation gives a lateral transport of terrigenous organic carbon of $0.34 \mathrm{~g} \mathrm{~m}^{-2} \mathrm{y}^{-1}$ at $1550 \mathrm{~m}$, which is $42 \%$ of the terrigenous POC flux $\left(0.81 \mathrm{~g} \mathrm{~m}^{-2} \mathrm{y}^{-1}\right)$ (Table 7). The order-of-magnitude correspondence with the laterally transported lithogenic matter supports our estimates. Considering all the assumptions used above, the calculated number should be considered a first-order estimate of lateral flux. Additionally, we show that the Betzer et al. (1984) formula for calculation of carbon flux seems to work also for the Arctic Ocean.

To show the complexity of the whole system we compared the trap data with results from nearsurface sediments of Core PS2757-7 (giant box corer) taken close to the location of the sediment trap (Fig. 1; Stein et al., 2001, 2004). Based on the accumulation rates of total organic carbon, which includes the marine as well as the terrigenous proportion (Stein et al., 2001), and the microscopical investigations of the organic carbon composition (maceral data show that $25 \%$ of the carbon is marine; Boucsein and Stein, 2000), only $0.4 \%$ of the 
marine organic carbon $\left(18 \mathrm{~g} \mathrm{~m}^{-2} \mathrm{y}^{-1}\right.$, Boetius and Damm, 1998) is buried (Table 7). Focusing on the terrigenous portion of organic carbon in the sediments $(75 \%$ based on maceral data) we found increasing values from the upper water column (trap data) to the sediment. Based on the assumption that the labile terrigenous organic compounds already have been degraded near the source of the material, we speculate that there must be a lateral transport of organic carbon away from the sediment surface, preventing burial of organic carbon. On the other hand, the comparison between the total sediment accumulation rate $\left(48 \mathrm{~g} \mathrm{~m}^{-2} \mathrm{y}^{-1}\right.$; Stein et al., 2004) and the sum of lithogenic and opal fluxes at $1550 \mathrm{~m}$ $\left(14.2 \mathrm{~g} \mathrm{~m}^{-2} \mathrm{y}^{-1}\right)$ shows that there must be up to $30 \mathrm{~g} \mathrm{~m}^{-2} \mathrm{y}^{-1}$ lateral input to the surface sediment (Table 7). This means that there must be different transport mechanisms for the accumulation of particulate organic carbon and the lithogenic fraction, even between $1550 \mathrm{~m}$ and the sediments surface $(1712 \mathrm{~m})$. One has to keep in mind, however, that the sedimentation rates are averages over long time scales while the vertical flux from the sediment traps are only 1-year measurements. Thus, the comparison carried out above, is only a rough estimate.

To solve the lateral transport issue and the problem of trapping efficiency, an additional multi-tracer approach using ${ }^{230} \mathrm{Th},{ }^{10} \mathrm{Be},{ }^{210} \mathrm{~Pb}$, and ${ }^{231} \mathrm{~Pa}$ has to be used. These tracers have been widely used in marine environments to determine particle removal rates, settling velocity of particles, and export of particulate organic carbon, and they may allow to distinguish between vertical and lateral transport of particulate organic matter in more detail (e.g., Yu et al., 2001; Rutgers van der Loeff et al., 2002; Trimble et al., 2004; Baskaran, 2005). These data, however, are not yet available for the area of sediment trap Lomo2.

\section{Conclusions}

- We can distinguish three different periods during 1995/1996: first the low productivity, low fluxes and ice-covered winter months (second half of November-March; Winter phase), second the higher flux period with ice-melting and ice-free conditions and high biogenic matter flux (AprilAugust; Biogenic phase), and third the highest flux period with ice-free conditions and highest lithogenic matter flux (September-end of October, Lithogenic phase).
- Most of the autochthonous carbon is recycled in the upper $150 \mathrm{~m}$ (except for the diatom event during July/August).

- The Betzer et al. (1984) formula for calculation of carbon flux seems to work also for the Arctic Ocean.

- At $1550 \mathrm{~m}$ depth we estimate a lateral input of $42 \%$ (based on terrigenous organic carbon) and $64 \%$ (based on lithogenic matter). In addition, sea-ice transport is of major importance.

- Accumulation on the southern Lomonosov Ridge is strongly influenced by the outflow of the Lena River, exhibiting relatively high vertical terrestrial POC export in September/October.

\section{Acknowledgements}

The authors thank the captain and the crew of R.V. Polarstern and the late C. Darnall for their help in installation and recovery of the mooring. Additionally, we thank Christiane Lorenzen, Michael Templin, and Martina Siebold for technical assistance, and Eduard Bauerfeind for creating the flux figures. The paper has benefited from thoughtful comments of three anonymous reviewers.

\section{References}

Ackman, R.G., Tocher, C.S., McLachlan, J., 1968. Marine phytoplankton fatty acid. Journal of Fishery Research Board Canada 25, 1603-1620.

Bareiss, J., Görgen, K., 2005. Spatial and temporal variability of sea ice in the Laptev Sea: analyses and review of satellite passive-microwave data and model results, 1972-2002. Global and Planetary Change 48, 28-54.

Baskaran, M., 2005. Interaction of sea ice sediments and surface sea water in the Arctic Ocean: evidence from excess ${ }^{210} \mathrm{~Pb}$. Geophysical Research Letters 32, L12601.

Bauerfeind, E., 2004. North east water polynya. In: Stein, R., Macdonald, R.W. (Eds.), The Organic Carbon Cycle in the Arctic Ocean. Springer, Berlin, pp. 106-109.

Behrends, M., Hoops, E., Peregovich, B., 1999. Distribution patterns of heavy minerals in Siberian rivers, the Laptev Sea and the eastern Arctic Ocean: an approach to identify sources, transport and pathways of terrigenous matter. In: Kassens, H., Bauch, H., Dmitrenko, I., Eicken, H., Hubberten, H.W., Melles, M., Thiede, J., Timokhov, L. (Eds.), Land-Ocean Systems in the Siberian Arctic: Dynamics and History. Springer, Berlin, pp. 265-286.

Betzer, P.R., Showers, W.J., Laws, E.A., Winn, C.D., Ditullo, G.R., Kroopnick, P.M., 1984. Primary productivity and particle fluxes on a transect of the equator at $153^{\circ} \mathrm{W}$ in the Pacific Ocean. Deep-Sea Research 31, 1-11.

Blumer, M., Guillard, R.R.L., Chase, T., 1971. Hydrocarbons of marine phytoplankton. Marine Biology 8, 183-189. 
Boetius, A., Damm, E., 1998. Benthic oxygen uptake, hydrolytical potentials and microbial biomass at the Arctic continental slope. Deep-Sea Research I 45, 239-275.

Boucsein, B., Stein, R., 2000. Particulate organic matter in surface sediments of the Laptev Sea (Arctic Ocean): application of maceral analysis as organic-carbon-source indicator. Marine Geology 162, 573-586.

Colony, R., Thorndike, A.S., 1984. An estimate of the mean field of Arctic Sea ice motion. Journal of Geophysical Research 89, 10623-10629.

Comiso, J.C., 2002. A rapidly declining perennial sea ice cover in the Arctic. Geophysical Research Letter 29 (20), 1956.

Comiso, J.C., Parkinson, C.L., 2004. Satellite-observed changes in the arctic. Physics Today 57 (8), 38-44.

Darby, D.A., Bischof, J.F., Jones, G.A., 1997. Radiocarbon chronology of depositional regimes in the western Arctic Ocean. Deep-Sea Research II 44, 1745-1757.

Darnall, C., Rudels, B., 1997. Mooring developtments. In: Rachor, E., (Ed.), Scientific Cruise Report of the Arctic Expedition ARK-XI/1 of R.V. "Polarstern" in 1995. Reports on Polar Research 226, pp. 26-28.

Dmitrenko, I., Golovin, P., Gribanov, V., Kassens, H., 1999. Oceanographic causes of transarctic ice transport of river discharge. In: Kassens, H., Bauch, H., Dmitrenko, I., Eicken, H., Hubberten, H.W., Melles, M., Thiede, J., Timokhov, L. (Eds.), Land-Ocean Systems in the Siberian Arctic: Dynamics and History. Springer, Berlin, pp. 73-92.

Eicken, H., 2004. The role of Arctic Sea ice in transporting and cycling terrestrial organic matter. In: Stein, R., Macdonald, R.W. (Eds.), The Organic Carbon Cycle in the Arctic Ocean. Springer, Berlin, pp. 45-53.

Eicken, H., Reimnitz, E., Alexandrov, V., Martin, T., Kassens, H., Viehoff, T., 1997. Sea-ice processes in the Laptev Sea and their importance for sediment export. Continental Shelf Research 17, 205-233.

Eicken, H., Kolatschek, J., Freitag, J., Lindemann, F., Kassens, H., Dmitrenko, I., 2000. Identifying a major source area and constraints on entrainment for basin-scale sediment transport by Arctic Sea ice. Geophysical Research Letters 27, 1919-1922.

Fahl, K., Kattner, G., 1993. Lipid content and fatty acid composition of algal communities in sea-ice and water from Weddell Sea (Antarctica). Polar Biology 13, 405-409.

Fahl, K., Stein, R., Gaye-Haake, B., Gebhardt, C., Kodona, L.A., Unger, D., Ittekkot, V., 2003. Biomarkers in surface sediments from the $\mathrm{Ob}$ and Yenisei estuaries and the southern Kara Sea: evidence for particulate organic carbon sources, pathways and degradation. In: Stein, R., Fahl, K., Fütterer, D.K., Galimov, E., Stepanets, O. (Eds.), Siberian River Run-off in the Kara Sea: Characterisation, Quantification, Variability, and Environmental Significance, Proceedings in Marine Science. Elsevier, Amsterdam, pp. 329-348.

Fischer, G., Wefer, G., 1991. Sampling, preparation and analysis of marine particulate matter. In: Hurd, D.C., Spencer, D.W. (Eds.), Marine Particles: Analysis and Characterization. Geophysical Monography no. 63. American Geophysical Union, pp. 391-397.

Fischer, G., Wefer, G., Romero, O., Dittert, N., Ratmeyer, V., Donner, B., 2003. Transfer of particle into the deep Atlantic and the global ocean: control of nutrient supply and ballast production. In: Wefer, G., Mulitza, S., Ratmeyer, V. (Eds.),
The South Atlantic in the Late Quaternary. Springer, Berlin, pp. 21-46.

Gaye, B., Fahl, K., Kodina, L.A., Lahajnar, N., Nagel, B., Unger, D., Gebhardt, A.C., submitted. Seasonal changes of particle matter flux in the southern central Kara Sea: bulk fluxes, amino acids, stable carbon and nitrogen isotops, sterols and fatty acids. Continental Shelf Research.

Graeve, M., Hagen, W., Kattner, G., 1994. Herbivorous or omnivorous? On the significance of lipid composition as trophic markers in Antarctic copepods. Deep-Sea Research I 41, 915-924.

Grahl, C., Boetius, A., Nöthig, E.-M., 1999. Pelagic-benthic coupling in the Laptev Sea affected by sea ice. In: Kassens, H., Bauch, H., Dmitrenko, I., Eicken, H., Hubberten, H.W., Melles, M., Thiede, J., Timokhov, L. (Eds.), Land-Ocean Systems in the Siberian Arctic: Dynamics and History. Springer, Berlin, pp. 143-152.

Haas, C., Eicken, H., 2001. Interannual variability of summer sea ice thickness in the Siberian and central Arctic under different atmospheric circulation regimes. Journal of Geophysical Research 106 (C3), 4449-4462.

Hargrave, B., 2004. North water polynya. In: Stein, R., Macdonald, R.W. (Eds.), The Organic Carbon Cycle in the Arctic Ocean. Springer, Berlin, pp. 103-106.

Hebbeln, D., 2000. Flux of ice-rafted detritus from sea ice in the Fram Strait. Deep-Sea Research II 47 (9-11), 1773-1790.

Hebbeln, D., Wefer, G., 1991. Effects of ice coverage and icerafted material on sedimentation in the Fram Strait. Nature 350, 409-411.

Heiskanen, A.-S., Keck, A., 1996. Distribution and sinking rates of phytoplankton, detritus, and particulate biogenic silica in the Laptev Sea and Lena River (Arctic Siberia). Marine Chemistry 53, 229-245.

Holmes, R.M., McClelland, J.W., Peterson, B.J., Shiklomanov, A.I., Zhulidov, A.V., Gordeev, V.V., Bobrovitskaya, N., 2002. A circumpolar perspective on fluvial sediment flux to the Arctic Ocean. Global Biogeochemical Cycles 16 (4), 1098.

Huang, W.Y., Meinschein, 1976. Sterols as source indicators of organic material in sediments. Geochimica et Cosmochimica Acta 40, 323-330.

Ittekkot, V., 1988. Global trends in the nature of organic matter in river suspensions. Nature 332, 436-438.

Jokat, W., 2005. The sedimentary structure of the Lomonosov Ridge between $88^{\circ} \mathrm{N}$ and $80^{\circ} \mathrm{N}$ : consequences for tectonic and glacial processes. Geophysical Journal International 163, 698-726.

Kates, K., Volcani, B.E., 1966. Lipid components of diatoms. Biochemica et Biophysica Acta 116, 264-278.

Kattner, G., Gercken, G., Eberlein, K., 1983. Development of lipids during a spring plankton bloom in the northern North Sea. Marine Chemistry 65, 149-162.

Krishnamurthy, R.V., Machavaram, M., Baskaran, M., Brooks, J.M., Champ, M.A., 2001. Organic carbon flow in the $\mathrm{Ob}$ Yenisey Rivers and Kara Sea of the Arctic region. Marine Pollution Bulletin 42 (9), 726-732.

Martin, T., Augstein, E., 2000. Large-scale drift of Arctic Sea ice retrieved from passive microwave satellite data. Journal of Geophysical Research 105 (C4), 8775-8788.

Moran, S.B., 2004. Regional variability in POC Export flux in the Arctic Ocean determined using ${ }^{234}$ Th as a tracer. In: Stein, R., 
Macdonald, R.W. (Eds.), The Organic Carbon Cycle in the Arctic Ocean. Springer, Berlin, pp. 126-130.

Nichols, P.D., Jones, G.J., de Leeuw, J.W., Johns, R.B., 1984. The fatty acid and sterol composition of two marine dinoflagellates. Phytochemistry 23 (5), 1043-1047.

Noji, T.T., Miller, L.A., Skjelvan, I., Falck, E., Børsheim, K.Y., Rey, F., Urban-Rich, J., Johannessen, T., 2001. Constraints on carbon draw down and export in the Greenland Sea. In: Schäfer, P., Ritzrau, W., Schlüter, M., Thiede, J. (Eds.), The Northern North Atlantic: A Changing Environment. Springer, Berlin, pp. 39-52.

Nørgaard-Pedersen, N., Spielhagen, R.F., Thiede, J., Kassens, H., 1998. Central Arctic surface ocean environment during the past 80,000 years. Paleoceanography 13, 193-204.

Nürnberg, D., 1996. Biogenic barium and Opal in shallow Eurasian shelf sediments in relation to the pelagic Arctic Ocean environment. In: Stein, R., Ivanov, G.I., Levitan, M.A., Fahl, K., (Eds.), Surface-sediment composition and sedimentary processes in the central Arctic Ocean and along the Eurasian Continental Margin. Reports on Polar Research no. 212, pp. 96-118.

O'Brien, M.C., MacDonald, R.W., Melling, H., Iseki, K., 2006. Particle fluxes and geochemistry on the Canadian Beaufort Shelf: implications for sediment transport and deposition. Continental Shelf Research 26, 41-81.

Okolodkov, Yu.B., 1992. Algae in the Ice of the Laptev Sea, vol. 29. Novosti sistematiki nizshikh rastenii, Leningrad, Russia, pp. 29-34.

Pagels, U., 1991. Sedimentologische Untersuchungen und Bestimmungen der Karbonatlösung in spätquartären Sedimenten des östlichen Arktischen Ozeans. Ph.D. Thesis, Kiel University, 106pp.

Peinert, R., Bauerfeind, E., Gradinger, R., Haupt, O., Krumbholz, M., Peeken, I., Werner, I., Zeitzschel, B., 2001. Biogenic particle sources and vertical flux patterns in the seasonally ice-covered Greenland Sea. In: Schäfer, P., Ritzrau, W., Schlüter, M., Thiede, J. (Eds.), The Northern North Atlantic: a changing environment. Springer, Berlin, pp. 69-79.

Peinert, R., Noji, T.T., 2004. Greenland Sea. In: Stein, R., Macdonald, R.W. (Eds.), The Organic Carbon Cycle in the Arctic Ocean. Springer, Berlin, pp. 109-112.

Prahl, F.G., Muehlhausen, L.A., 1989. Lipid biomarkers as geochemical tools for paleoceanographic study. In: Berger, W.H., et al., (Eds.), Productivity of the Ocean: Past and Present. Life Science Research Report no. 44, pp. 271-290.

Rachold, V., Eicken, H., Gordeev, V.V., Grigoriev, M.N., Hubberten, H.-W., Lisitzin, A.P., Shevchenko, V.P., Schirmeister, L., 2004. Modern terrigenous organic carbon input to the Arctic Ocean. In: Stein, R., Macdonald, R.W. (Eds.), The Organic Carbon Cycle in the Arctic Ocean. Springer, Berlin, pp. 33-55.

Rachor, E., 1997. Scientific Cruise Report of the Arctic Expedition ARK-XI/1 of RV "Polarstern" in 1995. Reports on Polar Research no. 226, 157pp.

Rigor, I., Colony, R., 1997. Sea-ice production and transport of pollutants in the Laptev Sea, 1979-1993. Science of Total Environment 202, 89-110.

Rudels, B., Muench, R.D., Gunn, J., Schauer, U., Friedrich, H.J., 2000. Evolution of the Arctic Ocean boundary current north of the Siberian shelves. Journal of Marine Systems 25, 77-99.
Rutgers van der Loeff, M.M., Meyer, R., Rudels, B., Rachor, E., 2002. Resuspension and particle transport in the Benthic Nepheloid layer in and near Fram Strait in relation to faunal abundances and ${ }^{234} \mathrm{Th}$ depletion. Deep-Sea Research I 49 (11), 1941-1958.

Sakshaug, E., 2004. Primary and secondary production in the Arctic Ocean. In: Stein, R., Macdonald, R.W. (Eds.), The Organic Carbon Cycle in the Arctic Ocean. Springer, Berlin, pp. 57-81.

Schlitzer, R., 2002. Carbon export fluxes in the Southern Ocean: results from inverse modeling and comparison with satellite based estimates. Deep-Sea Research II 49, 1623-1644.

Stein, R., 1996. Organic-carbon and carbonate distribution in Eurasian continental margin and Arctic Ocean deep-sea surface sediments: Sources and pathways. In: Stein, R., Ivanov, G.I., Levitan, M.A., Fahl, K., (Eds.), Surface-sediment composition and sedimentary processes in the central Arctic Ocean and along the Eurasian Continental Margin. Reports on Polar Research no. 212, pp. 243-267.

Stein, R., Fahl, K., 2004. The Laptev Sea: distribution, sources, variability and burial of organic carbon. In: Stein, R., Macdonald, R.W. (Eds.), The Organic Carbon Cycle in the Arctic Ocean. Springer, Berlin, pp. 213-237.

Stein, R., Korolev, S., 1994. Shelf-to-basin sediment transport in the eastern Arctic Ocean. Reports on Polar Research 144, $87-100$.

Stein, R., Grobe, H., Wahsner, M., 1994. Organic carbon, carbonate, and clay mineral distributions in eastern central Arctic Ocean surface sediments. Marine Geology 119, 269-285.

Stein, R., Boucsein, B., Fahl, K., Garcia de Oteyza, T., Knies, J., Niessen, F., 2001. Accumulation of particulate organic carbon at the Eurasian continental margin during Late Quarternary times: controlling mechanisms and paleoenvironmental significance. Global and Planetary Change 31, 87-102.

Stein, R., Schubert, C., MacDonald, R.W., Fahl, K., Harvey, H.R., Weiel, D., 2004. The central Arctic Ocean: distribution, sources, variability and burial of organic carbon. In: Stein, R., Macdonald, R.W. (Eds.), The Organic Carbon Cycle in the Arctic Ocean. Springer, Berlin, pp. 295-314.

Trimble, S.M., Baskaran, M., Porcelli, D., 2004. Scavenging of thorium isotopes in the Canadian Basin of the Arctic Ocean. Earth and Planetary Science Letters 222, 915-932.

Volkman, J.K., 1986. A review of sterol markers for marine and terrigenous organic matter. Organic Geochemistry 9, 83-99.

von Bodungen, B., Wunsch, M., Füderer, H., 1991. Sampling and analysis of suspended particles in the North Atlantic. In: Hurt, D.C., Spencer, D.W. (Eds.), Marine Particles: Analysis and Characterization. Geophysical Monography no. 63. American Geophysical Union, pp. 47-53.

Wassmann, P., Bauerfeind, E., Fortier, M., Fukuchi, M., Hargrave, B., Moran, B., Noji, T., Nöthig, E.-M., Olli, K., Peinert, R., Sasaki, H., Shevchenko, V.P., 2004. Particulate Organic Carbon Flux to the Arctic Ocean Sea Floor. In: Stein, R., Macdonald, R.W. (Eds.), The Organic Carbon Cycle in the Arctic Ocean, Springer, Berlin, pp. 101-138.

Wakeham, S.G., Hedges, J.I., Lee, C., Peterson, M.A., Hernes, P.J., 1997. Molecular indicators of diagenetic status in marine 
organic matter. Geochimica et Cosmochimica Acta 61 (24), 5363-5369.

Yu, E.-F., Francois, R., Bacon, M.P., Honjo, S., Fleer, A.P., Manganini, S.J., Rutgers van der Loeff, M.M., Ittekot, V., 2001. Trapping efficiency of bottom-tethered sediment traps estimated from the intercepted fluxes of Th and $\mathrm{Pa}$. Deep-Sea Research I 48, 865-889.
Yunker, M.B., Macdonald, R.W., Veltkamp, D.J., Cretney, W.J., 1995. Terrestrial and marine biomarkers in a seasonally icecovered Arctic estuary-integration of multivariate and biomarker approaches. Marine Chemistry 49, 1-50.

Zernova, V.V., Nöthig, E.-M., Shevchenko, V.P., 2000. Vertical microalgae flux in the northern Laptev Sea. Oceanology 40, 801-808. 